\title{
Comparative Biosorption Capacity of Copper and Chromium by Bacillus Cereus
}

\author{
Saravana Raj A ${ }^{1 *}$, Vinosh Muthukumar $P^{2}$, Bharathiraja $B^{3}$, Priya $\mathbf{M}^{4}$ \\ ${ }^{1,2,3}$ Department of Chemical Engineering, Vel Tech High Tech Dr.Rangarajan Dr.Sakunthala Engineering College, Avadi, Chennai \\ ${ }^{4}$ Departmenmt of Biotechnology, PRIST University-Chennai Campus, Manami, ECR, Chennai \\ *Corresponding author E-mail: saravanarajchemical@gmail.com
}

\begin{abstract}
Biosorption of heavy metals by bacteria is one such effective and eco-friendly method being adopted frequently for environmental applications. The present work reveals the comparative adsorption capacity of Copper and Chromium on the surface of Bacillus Cereus, aerobic, gram positive bacteria. Hexavalent chromium is toxic, non-biodegradable and persistent in nature, Copper is equally toxic when exceeds the permissible limit. Batch experimental studies were conducted in shake flask method to optimize the parameters such as $\mathrm{pH}$, Reaction time, Biosorbent dose and Initial metal concentration. One of four parameters was varied keeping the other three constants and the optimum reaction time was found to be 24 hours. At an Optimum $\mathrm{pH}$ level of $7 \pm 2$ with the optimum initial metal concentration of $100 \mathrm{ppm}$ the biosorption capacity was found to be 54 percent and 60 percent for Copper and Chromium respectively.
\end{abstract}

Keywords: Bacillus Cereus; Biosorption; Chromium; Copper, Heavy metal.

\section{Introduction}

Heavy metal is a general collectiveterm that applies to the group of metals and metalloids with density greater than $4 \pm 1$ $\mathrm{g} / \mathrm{cm}^{3}$. Since heavy metals cannot be degraded or destroyed, they persist in the environment. Some of the heavy metals which will pose environmental problems when exceeds their respective permissible limits are cadmium, chromium, copper, mercury, lead, zinc, arsenic, boron, and the platinum group metals. Chromium released in the effluent from chrome tanning and chrome plating industries and copper pollution from mining, milling, refining of copper ores, electroplating and petroleum industries pose serious environmental problem listed in Table 2 below [1].

Chromium and Copper concentration in drinking water should not exceed $0.05 \mathrm{mg} / \mathrm{L}$ as per WHO norms and ISI standards as listed in Table 1. Industrial or sewage effluents should not exceed 3.0 $\mathrm{mg} / \mathrm{L}$ if it is being let out into inland surface or into marine coastal plane.

Heavy metals can enter into lakes, rivers, other water bodies and groundwater by industrial and consumer waste. Heavy metal toxicity can result in damaged or reduced mental and central nervous function and damages blood composition, lungs, kidneys, liver, and other vital organs. Long-term exposure may result in slowly progressing physical, muscular, and neurological degenerative processes that mimic Alzheimer's disease, Parkinson's disease, muscular dystrophy, and multiple sclerosis [2]

Methods such as, Chemical precipitation, Filtration, Membrane separation, Ion exchange etc available to reduce the heavy metal pollution from effluent or from the environment are expensive, labour consuming and generate secondary wastes which are difficult to manage. On the other hand biosorption serves to be the ecofriendly and comparatively easier method for the reduction of heavy metal pollution from the effluent or from the environment [3].

\begin{tabular}{|c|c|c|}
\hline \multicolumn{2}{|c|}{ Table1: Permissible limit for drinking water [4] } \\
\hline Heavy metals & Standards & Permissible limit \\
\hline Arsenic & IS: $10500-1991$ & $0.05 \mathrm{mg} / 1$ \\
\hline Chromium & IS: $10500-1991$ & $0.05 \mathrm{mg} / 1$ \\
\hline Copper & IS: $10500-1991$ & $0.05 \mathrm{mg} / 1$ \\
\hline Lead & IS: $10500-1991$ & $0.05 \mathrm{mg} / 1$ \\
\hline Mercury & IS: $10500-1991$ & $0.001 \mathrm{mg} / 1$ \\
\hline Zinc & IS: $10500-1991$ & $2 \mathrm{mg} / 1$ \\
\hline
\end{tabular}

Table 2: Sources and significance of trace elements

\begin{tabular}{|c|c|c|c|}
\hline S.No. & Element & Source & $\begin{array}{c}\text { Effects and Signifi- } \\
\text { cance }\end{array}$ \\
\hline 1 & Arsenic & $\begin{array}{l}\text { Mining by-product, } \\
\text { pesticides, chemical } \\
\text { waste }\end{array}$ & $\begin{array}{l}\text { Toxic, possibly car- } \\
\text { cinogenic }\end{array}$ \\
\hline 2 & Beryllium & $\begin{array}{l}\text { Coal, nuclear power } \\
\text { and space Industries }\end{array}$ & $\begin{array}{l}\text { Carcinogenic, Acute } \\
\text { and chronic toxicity }\end{array}$ \\
\hline 3 & Boron & $\begin{array}{l}\text { Coal, detergent } \\
\text { formulations, } \\
\text { industrial wastes }\end{array}$ & Toxic to some plants \\
\hline 4 & Cadmium & $\begin{array}{l}\text { Industrial discharge, } \\
\text { mining waste, metal } \\
\text { plating, water pipes }\end{array}$ & $\begin{array}{l}\text { Causes high blood } \\
\text { pressure and } \\
\text { Kidney, Replaces zinc } \\
\text { biochemically }\end{array}$ \\
\hline 5 & Copper & $\begin{array}{l}\text { Metal plating, indus- } \\
\text { trial and domestic } \\
\text { wastes, mining, } \\
\text { mineral leaching }\end{array}$ & $\begin{array}{l}\text { Essential trace element, } \\
\text { not very toxic to ani- } \\
\text { mals, toxic to plants } \\
\text { and algae at moderate } \\
\text { levels }\end{array}$ \\
\hline 6 & $\begin{array}{l}\text { Fluorine } \\
\text { (Fluoride) }\end{array}$ & $\begin{array}{l}\text { Natural geological } \\
\text { sources, industrial } \\
\text { wastes, water addi- } \\
\text { tive }\end{array}$ & $\begin{array}{l}\text { Prevents tooth decay at } \\
\text { above } 1 \mathrm{mg} / \text { liter, caus- } \\
\text { es mottled teeth and } \\
\text { bone damage at around } \\
5 \mathrm{mg} / \text { liter in water }\end{array}$ \\
\hline 7 & $\begin{array}{l}\text { Iodine } \\
\text { (Iodide) }\end{array}$ & $\begin{array}{l}\text { Industrial wastes, } \\
\text { natural brines, }\end{array}$ & Prevents goiter \\
\hline
\end{tabular}




\begin{tabular}{|c|c|c|c|}
\hline & & seawater intrusion & \\
\hline 8 & Iron & $\begin{array}{l}\text { Corroded metal, } \\
\text { industrial wastes, } \\
\text { acid mine drainage, } \\
\text { low ph water in } \\
\text { contact with iron } \\
\text { minerals }\end{array}$ & $\begin{array}{l}\text { Essential nutrient } \\
\text { (component of } \\
\text { hemoglobin), not very } \\
\text { toxic, damages material } \\
\text { (bathroom fixtures and } \\
\text { clothing) }\end{array}$ \\
\hline 9 & Lead & $\begin{array}{l}\text { Industry, mining, } \\
\text { plumbing, } \\
\text { coal, gasoline }\end{array}$ & $\begin{array}{l}\text { Toxicity (anemia, kid- } \\
\text { ney disease, } \\
\text { nervous system), wild- } \\
\text { life destruction }\end{array}$ \\
\hline 10 & Manganese & $\begin{array}{l}\text { Mining, industrial } \\
\text { waste, acid mine } \\
\text { drainage, microbial } \\
\text { action on manganese } \\
\text { minerals at low ph }\end{array}$ & $\begin{array}{l}\text { Relatively nontoxic to } \\
\text { animals, toxic to plants } \\
\text { at higher levels, stains } \\
\text { material (bathroom } \\
\text { fixtures and clothing) }\end{array}$ \\
\hline 11 & mercury & $\begin{array}{l}\text { Industrial waste, } \\
\text { mining, } \\
\text { pesticides, coal }\end{array}$ & $\begin{array}{l}\text { Acute and chronic } \\
\text { toxicity }\end{array}$ \\
\hline 12 & Molybdenum & $\begin{array}{l}\text { Industrial waste, } \\
\text { natural sources, } \\
\text { cooling-tower water } \\
\text { additive }\end{array}$ & $\begin{array}{l}\text { Possible toxic to ani- } \\
\text { mals, essential for } \\
\text { Plants }\end{array}$ \\
\hline 13 & Selenium & $\begin{array}{l}\text { Natural geological } \\
\text { sources, sulfur, coal }\end{array}$ & $\begin{array}{l}\text { Essential at low levels, } \\
\text { toxic at higher levels, } \\
\text { causes "alkali disease" } \\
\text { and "blind staggers" in } \\
\text { cattle, possibly }\end{array}$ \\
\hline
\end{tabular}

\section{Materials and Methods}

\subsection{Biosorbent/Biomass Preparation}

Bacillus cereus (a Gram-positive, rod-shaped bacteria) obtained from Central Leather Research Institute was used for the experiment. Bacillus cereus culture from freshly prepared agar plates were inoculated into 1 Litre conical flasks containing $500 \mathrm{~mL}$ of nutrient broth with beef extract $(3.0 \mathrm{~g})$, peptone $(6.0 \mathrm{~g})$, disodium phosphate $(1.0 \mathrm{~g})$, sodium chloride $(3.0 \mathrm{~g})$, dissolved in one liter of distilled water. The $\mathrm{pH}$ values of the solutions were adjusted to the optimum values $7 \pm 2$ using $0.1 \mathrm{~N} \mathrm{NaOH}$ and $0.1 \mathrm{~N} \mathrm{HNO}_{3}$. The cultures were grown at room temperature on an orbital shaker at $150 \mathrm{rpm}$ for $48 \mathrm{~h}$. Well grown culture solution was used for the biosorption experimental studies [6].

\subsection{Aqueous Solution Preparation}

Potassium chromate $\left(\mathrm{K}_{2} \mathrm{CrO}_{4}\right)$ and copper sulphate $\left(\mathrm{CuSO}_{4}\right)$ procured are of high pure and laboratory grade (Merck). The aqueous solution prepared by dissolving known quantities of the salts in distilled water are sterilized for about 15 minutes in autoclave and were used for the experiments. Initial and final concentration of the solution before and after the experiments was analysed using UV visible spectrophotometer (Perkin-Elmer B050-7805)[7].

\subsection{Experiments}

\section{a) Effect of $\mathbf{p H}$}

Initial solution concentration being 100ppm, Culture concentration being $10 \%$ and the contact time was maintained constant as 24 hours, the effect of $\mathrm{pH}$ on the adsoption capacity of $\mathrm{Cu}$ and $\mathrm{Cr}$ was studied in batch experiments. Solution $\mathrm{pH}$ was adjusted by $0.1 \mathrm{~N}$ $\mathrm{NaOH}$ and $0.1 \mathrm{~N} \mathrm{HNO}_{3}$. The experiment was repeated thrice and the average value of the three trials was plotted and shown in Fig.1

\section{b) Effect of Time}

Initial solution concentration being 100ppm, Culture concentration being $10 \%$ and the $\mathrm{pH}$ being maintaine at $7 \pm 2$, batch experiments was conducted to know the optimum time of contact to be maintained for maximum biosrption capacity. The experiment was repeated thrice and the average value of the three trials was plotted and shown in Fig.2

\section{c) Effect of Culture Concentration}

Maintaining the solution $\mathrm{pH}$ at the optimum value of $7 \pm 2$ and the Initial solution concentration being $100 \mathrm{ppm}$, the adsorption capacity at 24 hours was observed by variying the culture concentration from 1 to $10 \%$. The experiment was repeated thrice and the average value of the three trials was plotted and shown in Fig. 3

\section{d) Effect of Initial Concentration}

Maintaining the culture concentration at the optimum level of $10 \%$, optimum $\mathrm{pH}$ value at $7 \pm 2$, the adsorption capacity at 24 hours was observed by variying the initial metal concentration from $100 \mathrm{ppm}$ to $500 \mathrm{ppm}$. The experiment was repeated thrice and the average value of the three trials was plotted and shown in Fig.4

\section{Results and Discussion}

\subsection{Effect of $\mathbf{p H}$}

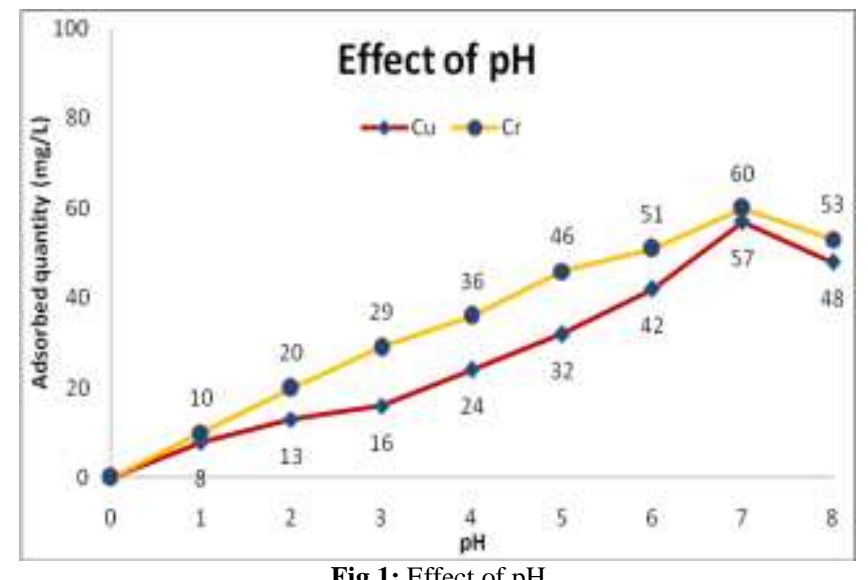

Fig 1: Effect of $\mathrm{pH}$

It was observed that the maximum adsorption capacity of $60 \mathrm{mg}$ and $57 \mathrm{mg}$ was observed for chromium and copper respectively at the optimum $\mathrm{pH}$ value of $7 \pm 2$. The ionic interaction between metal ion and the biosorbent functional group varies with varying $\mathrm{pH}$ value till 7 beyond which the adsorption capacity decreases because of the formation of soluble metal hydroxide in the solution [8]. The adsorption capacity was more or less equal higher for both chromium and copper due to the lower concentration of $\mathrm{H}^{+}$ and $\mathrm{H}_{3} \mathrm{O}^{+}$ions in the solution which makes the biomass surface capable of binding positive metal ions [9].

\subsection{Effect of Reaction Time}



Fig 2 : Effect of time 
Maximum adsorption capacity of 55mg for Copper and 61mg for chromium was adsobed by the biomass and equlibirium was attained almost at the end of 12 hours of contact time. More than $90 \%$ of maximum adsorption capacity such that $46 \mathrm{mg}$ for Copper and $54 \mathrm{mg}$ for chromium was attained during the 12 hour operation for both chromium and copper. More amount of metal ions available as adsorbate and more number of active sites avaible for adsorption during the first few hours of operation makes the operation to attain equilibrium posible [10]. The drop in adsorption rate after 24 hours might be due to the non availability of enough active sites or due to the less ionic concentration of the solution [11].

\subsection{Effect of Culture Concentration}

The biosorption capacity increases with the increase in the culture concentration. When $1 \%$ culture was added to the $100 \mathrm{ppm}$ solution the adsorption capacity was found to be 14 and $19 \mathrm{mg}$ for copper and chromium respectively and it reaches a maximum value of 58 and $61 \mathrm{mg}$ for the optimum culture concentration of $10 \%$.

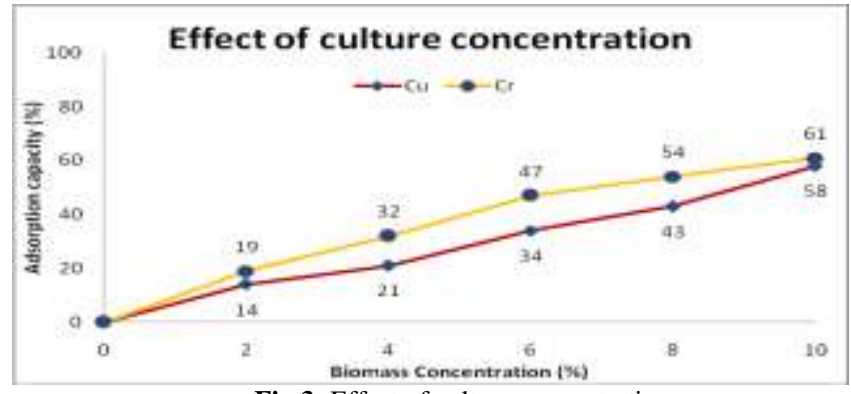

Fig 3: Effect of culture concentration

More amount of active sites available for biosorption when more amount of culture medium/ biosorbent added to the solution might be the reason for the for the increase in biosorption capacity when the biosorbent concentration increases[12]. Increase the concentration beyond $10 \%$ leads to the decrease in biosorption due to partia aggregation of cells which decreases the free active cites for metal binding.

\subsection{Effect of Initial Concentration}

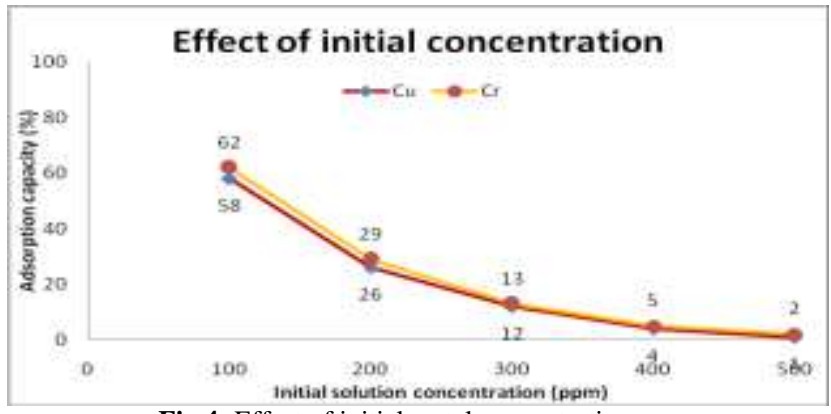

Fig 4: Effect of initial metal concentration

Initial metal concentration was varied from $100 \mathrm{ppm}$ to $500 \mathrm{ppm}$ and the biosorption capacity was observed. Maximum biosorption capacity 62 and $58 \mathrm{mg}$ was observed for Chromium and Copper respectively. Decrease in the biosorption capacity with the increase in the initial concentration might be due to the contamination of cell culture due to the higher concentration of heavy metal in the solution [13]. At about 500pm the adsorption capacity was almost zero and increases when the initial concentration was decreased from 500 to the optimum level of $100 \mathrm{pm}$ initial concentration.

\section{Conclusion}

Comparative analysis of the biosorption capacity of environmentally toxic heavy metals such copper and chromium onto the surface of bacteria, bacillus cereus was experimentally verified and it was found to be almost equal for both the metals. Scanning electron microscopic analysis, energy dispersive Spectroscopic analysis, FTIR would possibly confirm the experimentally obtained results which were presented in this article. Fitting the data's in the adsorption isotherms for validation, verifying the kinetics and thermodynamic parameters of the reaction would be the future scope of the present work presented in this article.

\section{Acknowledgement}

I thank Vel Tech for providing all the facility required to carry out the experiments.

\section{References}

[1] A.K.Shrivastava, A review on copper pollution and its removal from water bodies by pollution control technologies, Indian J. of Environmental Protection, Vol. 29, No. 6, June 2009.

[2] Rashmi Verma and Pratima Dwivedi, Heavy metal water pollutionA case study, Recent Research in Science and Technology, 5(5): 98-99, 2013.

[3] John Rose MercyBenila Smily and Pasumalai ArasuSumithra, Optimization of Chromium Biosorption by Fungal Adsorbent, Trichoderma sp. BSCR02 and its Desorption Studies, HAYATI Journal of Biosciences, Volume 24, Issue 2, April 2017, Pages 65-71

[4] Bureau of Indian Standards, Indian standard drinking water - specification (second revision), IS 10500: 2012

[5] A.Ş.Yargıç et al, Assessment of toxic copper(II) biosorption from aqueous solution by chemically-treated tomato waste, Journal of Cleaner Production, Volume 88, 1 February 2015, Pages 152-159

[6] Hassan Rezaei, Biosorption of chromium by using Spirulina sp., Arabian Journal of Chemistry, Volume 9, Issue 6, November 2016 Pages 846-853

[7] Robson Andreazza, Characterization of copper bioreduction and biosorption by a highly copper resistant bacterium isolated from copper-contaminated vineyard soil, Science of The Total Environment, Volume 408, Issue 7, 1 March 2010, Pages 1501-1507

[8] Mathivanan Krishnamurthy and R. Rajaram, Removal of Cd(II) and $\mathrm{Cu}$ (II) from Aqueous Solutions by Pseudomonas stutzeri KMNTT01 Biomass, Environmental Processes An International Journal, Volume 3 Number 4, (2016) 3:857-874.

[9] MarinaFomina et al, Biosorption: current perspectives on concept, definition and application, Bioresource Technology, Volume 160, May 2014, Pages 3-14

[10] JinsongHe and J. PaulChen, A comprehensive review on biosorption of heavy metals by algal biomass: Materials, performances, chemistry, and modeling simulation tools, Bioresource Technology, Volume 160, May 2014, Pages 67-78

[11] M D Mullen et al, Bacterial sorption of heavy metals, Applied and Environmental Microbiology, December 1989 vol. 55 no. 123143 3149

[12] Hanjun Guo et al, Bioremediation of heavy metals by growing hyperaccumulaor endophytic bacterium Bacillus sp. L14, Bioresource Technology, Volume 101, Issue 22, November 2010, Pages 8599 8605

[13] Mohammad Oves et al, Biosorption of heavy metals by Bacillus thuringiensis strain OSM29 originating from industrial effluent contaminated north Indian soil, Saudi Journal of Biological Sciences, Volume 20, Issue 2, April 2013, Pages 121-129

[14] Shankar Congeevaram et al, Biosorption of chromium and nickel by heavy metal resistant fungal and bacterial isolates, Journal of Hazardous Materials, Volume 146, Issues 1-2, 19 July 2007, Pages 270-277 